\title{
ACADEMIC P.A. LAVROV: THE FATE OF CYRILO-METHODIAN RESEARCH IN BOLSHEVIK AND SOVIET RUSSIA ${ }^{1}$
}

\begin{abstract}
:
The article refers to the creative path of the famous Slavicist, academic P.A. Lavrov (1856-1929), who for many years gave lectures on Slavonic philology and history of Slavic peoples at the Moscow and St Petersburg Universities. He contributed much to the development of Slavistics, studying the activities of Slavic first educators Cyril and Methodius, their disciples Clement of Ohrid and Naum of Ohrid, the paleography of the old Slavic manuscripts and other important areas of this field of science. During his long life, he caught both the rise of Russian Cyrilo-Methodievan studies and the eve of its collapse under the Bolsheviks, who considered the idea of Slavic community bourgeois and harmful.
\end{abstract}

\section{Keywords:}

Slavicism, Southern Slavs, Petar II Petrovich Negosh, Bulgarian language, Athos, old Slavic manuscripts, Slavic paleography, Cyril and Methodius, Clement of Ohrid and Naum of Ohrid.

АННОТАЦИЯ: Н.С. ГУСЕВ. «АКАДЕМИК П.А. ЛАВРОВ: СУДЬБА КИРИЛЛО-МЕФОДИЕВСКИХ ИССЛЕДОВАНИЙ В БОЛЬШЕВИСТСКОЙ И СОВЕТСКОЙ РОССИИ».

В статье речь идет о творческом пути известного слависта, академика П.А. Лаврова (1856-1929), много лет читавшего лекции по славянской филологии и истории славянских народов в Московском и Санкт-Петербургском университетах. Он внес большой вклад в развитие славистики, занимаясь изучением деятельности славянских первоучителей Кирилла и Мефодия, их учеников Климента Охридского и Наума Охридского, палеографией древних славянских рукописей и другими важными направлениями данной области науки. За свою долгую жизнь он застал как расцвет российской кирилло-мефодиевистики, так и канун ее разгрома при большевиках, считавших идею славянской общности буржуазной и вредной.

\section{Ключевые слова:}

Славяноведение, южные славяне, Петар II Петрович Негош, болгарский язык, Афон, древнеславянские рукописи, славянская палеография, Кирилл и Мефодий, Климент Охридский и Наум Охридский.

Deter (in Rus. - Pyotr) Alekseevich Lavrov was born in Yaroslavl in 1856 into the family of an archpriest and professor of theology at Yaroslavl Demidov Law Lyceum, which largely determined the research interests of the future academic. After graduating from the local gymnasium, in 1858 he entered the historical and philological faculty of Moscow University. His original plans to

1 The work was carried out with the financial support of the RFBR (grant № 18-512-76004). 
study ancient Roman history were confounded by the uprising in Bosnia and Herzegovina, the Serbian-Turkish, and then the Russo-Turkish wars. Lavrov became interested in the Balkans, started to learn Serbian, and chose The Historical and Literary Analysis of the Kosovo Epics as the topic of his thesis. In 1880 he was attached to the department of Slavic dialects to prepare for a professorship under the guidance of professor Alexander Duvernois.

Four years later Lavrov was sent on a scientific trip for eight months to the Slavic lands. He had three tasks: collecting materials for a monograph on the literary activities of the Montenegrin ruler, Petar II Petrovich Negosh, studying folklore materials in connection with

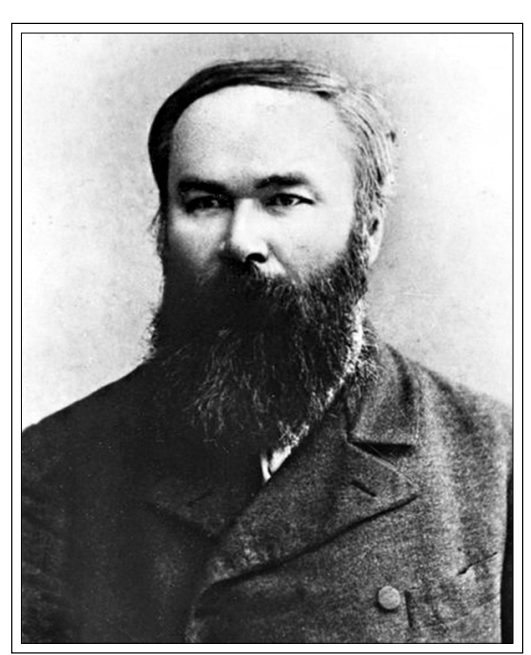

Photo of PA. Lavrov written sources, and exploring the connections between Serbian and Croatian literature. During the trip, Lavrov visited Novi Sad, Belgrade, Zagreb, Dalmatia and Montenegro, and worked in the archives and libraries of Vienna and Budapest. On the basis of the material he had collected, in 1887 he defended his dissertation on the biography and literary activity of Petar II Petrovich Negosh, after which he became a private-docent with the goal of teaching Slavic philology.

However, before this could happen, a tragic event occurred that changed the direction of his scientific research. Alexander Duvernois died in 1886 and he had to complete the work on the dictionary of the Bulgarian language which his teacher had been preparing. This forced Lavrov to engage closely in the new Slavic language and its history, and this resulted in a doctoral dissertation, An Overview of the Sound and Formal Features of the Bulgarian Language, which he defended in 1893. The study published for the first time a number of important texts of the 14th-18th centuries and a brief historical dictionary of the Bulgarian language. His work on the South Slavic translation of the sermons of Damaskinos Stouditis was a continuation of research in this direction.

In 1892 Lavrov was invited to take up a post as professor of Slavic philology at the University of Warsaw, but he was busy preparing his doctoral dissertation and a new trip to the Slavic lands, so he asked to postpone the start of his work at this university. As a result, this position was accepted by P. A. Kulakovsky, and Lavrov was offered the chair of the Russian language, which he refused, because he wanted to continue his Slavic studies.

In 1894 Lavrov set off on a trip to Mt. Athos. On the way he visited Odessa, where he studied the archive of the famous scholar V.I. Grigorovich, and Constantinople. On the Holy Mountain, Lavrov stopped at the Russian Panteleimon monastery, worked in the Serbian Hilandar and Bulgarian Zograph monasteries. 
Here, the Russian scholar discovered new manuscripts, primarily of an apocryphal nature, clarified information about several others, and then went to work in the library of Sofia. The written documents studied during the trip were published and brought Lavrov recognition as a connoisseur of ancient Slavic writing. Throughout his life, Lavrov studied the works of Clement of Ohrid, a disciple of the first Slavic teachers, Cyril and Methodius, wrote many articles about him, and established his authorship of several texts in a comparative way. Lavrov also studied another disciple of the brothers from Thessalonica: St Naum, whose unknown biography was discovered on Athos and then published. The result of many years of studying this research was turned into a series of books that were published at a much later time. The writings of Cyril and Methodius in Old Cburch Slavonic (1928) is essentially an encyclopedia of Cyril and Methodius, which offers a critical review of almost all of the sources and research related to the initial stage of Slavic writing. The book paid a great deal of attention to the language and style of the documents to determine the place and time of their creation, analyzed in detail the main sources about the lives and work of Sts Cyril and Methodius. The second work, Materials on the history of the emergence of the ancient Slavic writing (1930), is a set of the most important documents of the initial period of Slavic writing. This book was published after the death of the scholar.

Immediately after the trip, Lavrov continued to lecture at Moscow University. Lithographic editions of his courses on the history of the Czech Republic and Bulgaria have been preserved. The first was less original, although he demonstrated a deep knowledge of existing literature; for the second, he relied largely on the results of his own work. As a result, he expressed advanced ideas for his time. Thus, he refuted M. S. Drinov's assertion that the Slavs settled the Balkan Peninsula already in the third century, proved the Turkic origin of the Proto-Bulgarians, indicating that they were assimilated already in the ninth century, and stressed the socio-economic basis of the Bogomil heretical movement.

However, there was no permanent position for Peter Alekseevich at Moscow University, and in 1898 he accepted an offer to take up a professorship at Novorossiysk University in Odessa. However, after the retirement of V.I. Lamansky, the position of department head of Slavic philology at St. Petersburg University became vacant, and Lavrov moved to the capital. As S.F. Platonov noted in his presentation of the new professor to the faculty council, "the solid academic reputation of P.A. Lavrov, as well as his never-flagging scholarly zeal, serve as the basis for wishing him to enter our midst." At the university, Lavrov taught courses on Slavic languages, literature, and South Slavic paleography. The latter topic became very fruitful for the scholar, apparently largely thanks to his friendship with the Serbian philologist A. Belich, who, at the request of his Petersburg colleague, sent pictures of the South Slavic manuscripts. In 1905 and 1916 Lavrov published albums of photographs and prepared a major work, The Paleographic Review of Cyrillic Writing (1914). It analyzed the lettering of manuscripts of the 
11 th-18th centuries, providing the features of individual groups of manuscripts and schools of writing, and proposed a detailed classification of South Slavic manuscripts according to paleographic features.

For his services, in 1902 Lavrov was elected a corresponding member of the Russian Academy of Sciences; in 1906, a corresponding member of the Serbian Academy of Sciences and Arts; and in 1911, a member of the Yugoslavian Academy.

Concurrent with his scientific activity, Lavrov also took part in public life, protecting the interests of the Slavs, primarily the Serbs. He lectured in Russian capitals and in the provinces on topical issues of the Balkans, published brochures on events in the Balkan peninsula: on the annexation of Bosnia and Herzegovina by the Austro-Hungarian Empire, the Balkan wars, the unification of Serbs and Croats, etc. He was a member of various public organizations, i.e., the Society of Slavic Scientific Unity.

Well aware that the time of an encyclopedic approach to the study of the Slavic peoples had passed, Lavrov in 1901 proposed the creation of three Slavic departments: philology, literature and history, insisting on the creation of at least two, the Department of Slavic Philology, the History of Slavic Literature, and the Department of the History of Slavs. Until 1914, Lavrov tried to achieve the establishment of a new department, but to no avail. But then there was the First World War, and then the revolution that changed everything.

In 1916 Lavrov prepared Slavic sources for the life and works of Cyril and Methodius. The work was approved for publication by the Academy of Sciences, but the revolution followed, and the possibility of publication disappeared. He then turned to his friend, A. Belich, with a request for publication, but even in post-war Belgrade, times were not easy.

Lavrov himself did not accept the revolution; first of all, he was oppressed by the arbitrariness of the new government, the degraded situation in which scientists fell. "We are suffocating from violence," he wrote to his friend in the summer of 1918. At that time he seriously thought about leaving Russia and going to the Slavic countries, but for some unknown reason he stayed. In 1923 Lavrov was elected a full member of the Academy of Sciences, and when the Slavic Scientific Commission was established, he became its actual head. Nevertheless, the situation had not fundamentally changed. The scholars' small salaries were increasingly devalued in the difficult economic situation. An ideological attack began on science, including philology. Scholars were required to approach everything from a Marxist, international position and to abandon "irrelevant" topics, which often meant ceasing to mention the common Slavic past and the study of church texts. Thus, the first meeting of the commission took place only in 1925; the first volume of its works was published in 1930 (this was Lavrov's aforementioned book); and in 1924 he, among many others, was not sent to Prague to attend the Congress of Slavic Geographers and Ethnographers. He then complained to his colleague in a letter: "Here they have made a yoke for themselves, the worst of 
all they have suffered so far. This terrible evil attack on everything national, on everything sacred to us, a mockery of antiquity." The attack on the Academy of Sciences was also expressed in constant attempts to liquidate the Department of Russian Language and Literature. But it turned out that in Kiev, in contrast to central Russia, scientific and religious topics were more tolerated. This explains the fact that Lavrov's most important work on Cyril and Methodius was published in 1928 in Kiev in the Ukrainian language. The author was skeptical about publishing it in other than Russian, because he believed that this would make the work inaccessible to the masses.

In January of the following year, a campaign began that dealt a significant blow to the Russian humanities. In the 1929 election of academics, several Communist candidates were voted down. The new authorities did not forgive such arbitrariness, especially since

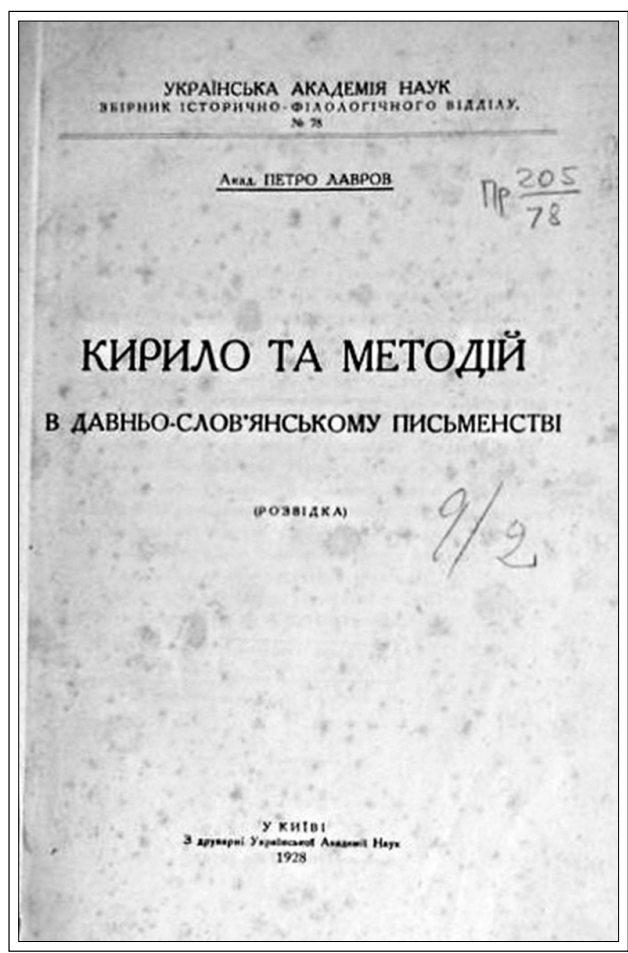

One of the most important works by P.A. Lavrov: "Cyril and Methodius in the long-words's words" the first fabricated trials had already begun. Clouds were gathering over those scholars who were unable to adapt to the Soviet regime. In this regard, no matter how wrong it may sound, Lavrov was "lucky" to die in time. On 24 November 1929 he died and was buried near the university, in the Smolensk cemetery in St. Petersburg. Already in January 1930, the Soviet security officers sent a note to the country's leadership confirming "the existence of a monarchist group in the Academy of Sciences." S.F. Platonov, who at one time had presented Lavrov to the council of the Faculty of History of St. Petersburg University, was "appointed" as the head of this fictitious organization, and the late Slavist himself was named among the group's members. Thus, the flywheel of the "Platonov's case," also called the "academic case," gathered speed. If Lavrov had survived the crucible of this process, then, undoubtedly, due to his anti-Soviet views, he would have already been involved in the "Slavic trial" a few years later. Lavrov's death thus saved him from moral and physical humiliation. However, his name was unjustifiably forgotten during the Soviet period. 


\section{BIBLIOGRAPHY}

Lapteva L.P. Istoriia slavianovedeniia v Rossii v kontse XIX - pervoi treti XX vv. Moscow, 2012.

Ot chuzhikh k svoim. Pis'ma vydaiushchikhsia predstavitelei russkoi intelligentsii nachala XX veka Aleksandru Belichu / sost. N. Blagoevich, A. Michich, I. Mrdzha. Belgrade, 2016.

Robinson MA. Sud'by akademicheskoi elity: otechestvennoe slavianovedenie (1917 nachalo 1930-kh godov). Moscow, 2004.

Slavianovedenie v dorevoliutsionnoi Rossii. Biobibliograficheskii slovar' / otv. red. V.A. D'iakov. Moscow, 1979.

\section{ILLUSTRATINOS}

1. Photo of P.A. Lavrov.

2. The "Dictionary of the Bulgarian language" by A.L. Duvernois, whose work was completed by P.A. Lavrov.

3. The doctoral dissertation of P.A. Lavrov "A review of the sound and formal features of the Bulgarian language."

4. The imprint of the lecture by P.A. Lavrov about the Second Balkan War of 1913, read in Petrozavodsk in 1913.

5. One of the most important works by P.A. Lavrov "Cyril and Methodius in the long-words's words."

6. P.A. Lavrov's work "Materials on the history of the emergence of ancient Slavic writing" which was published after his death. 